Гацелюк В.О. - Проблеми визначення змісту та обсягу криміналізації порушення...

\title{
ПРОБЛЕМИ ВИЗНАЧЕННЯ ЗМІСТУ ТА ОБСЯГУ КРИМІНАЛІЗАЦІЇ ПОРУШЕННЯ САНІТАРНИХ ПРАВИЛ І НОРМ ЩОДО ЗАПОБІГАННЯ ІНФЕКЦЙНИМ ХВОРОБАМ ТА МАСОВИМ ОТРУЕННЯМ В КОНТЕКСТІ ТЕОРІЇ ТА ПРАКТИКИ ПРОТИДІї ЗЛОЧИННОСТІ В УКРАЇНІ
}

\begin{abstract}
ГАЦЕЛЮК Віталій Олександрович - кандидат юридичних наук, старший науковий співробітник відділу проблем кримінального права, кримінологіі та судоустрою Інституту держави і права ім. В.М. Корецького НАН України
\end{abstract}

DOI:10.32782/LAW.2020.1.12

\begin{abstract}
Статья посвящена анализу содержания и объема криминализации нарушения правил и норм по предотвращению инфекционнъих болезней и массовъх отравлений с учетом решений законодателя, принятых с цеелью противодействия Коронавирусная болезни (COVID-19). На основании анализа законодательства о противодействии инфекиионньм заболеванием сделан въивод о ијелесообразности использования в тексте диспозиции статьи 325 Уголовного кодекса формулировки «правила, направленнъе на предотвращение возникновения и / или распространение инфекиионных болезней или массовых неинфекционных заболеваний (отравлений)». На основании анализа действующих норм уголовного законодательства и научнъгх позиций предложено возможньй путь совершенствования уголовного права в этом сегменте путем изложения статьи 325 в новой редакиии.
\end{abstract}

Ключевъие слова: криминализачия, инфекционная болезнь, отравление; состав преступления.

Одним із перших кроків законодавця у зв'язку із протидією поширенню коронавірусної хвороби хвороби (COVID-19) було внесення змін до статті 325 КК, що підтвердило вже традиційне ставлення законодавчого органу до кримінального законодавства як до універсального інструмента вирішення суспільних конфліктів. Проте, далеко не завжди переведення конфлікту в розряд кримінально-правових внаслідок збільшення кола криміналізованих діянь сприяє його вирішенню.
Екстраполюючи з формальної логіки інструментарій визначення змісту та обсягу поняття (в нашому випадку це склади злочину порушення санітарних правил і норм щодо запобігання інфекційним хворобам), спробуємо прослідкувати логіку законодавця при визначенні обсягу криміналізації порушення санітарних правил і норм щодо запобігання інфекційним хворобам та масовим отруєнням.

Складно при цьому заперечити наступну думку: законотворчий процес і вся законодавча практика повинні мати творчий, багатоаспектний, науково обгрунтований характер, оскільки він не просто віддзерка^ює зміни і розвиток зовнішнього світу, а $\epsilon$ складним процесом його цілеспрямованого, концентрованого і нормативно-правового перетворення. Лише завдяки цьому результати законотворчості - закони отримують силу активного зворотного впливу на навколишній світ. Ефективне наукове, нормативно-правове та організаційне забезпечення законотворчого процесу сприятиме подальшому динамічному розвитку України як демократичної правової держави, всебічній реалізації прав і свобод їі громадян, формуванню в нашій країні сучасного, розвинутого громадянського суспільства[1; 14].

Безумовно, кризова пандемічна ситуація зумовлює актуальність якомога швидких рішень, проте, не можна втрачати баланс між швидкістю законодавчих змін та рівнем їх підготовленості. В цьому контек- 


\section{Кримінальне право, кримінальний процес та криміналістика}

сті, оцінці останньої редакції статті 325 КК сприятиме застосування історичного методу для визначення етапів розвитку відповідної кримінально-правової заборони 3 часу набрання чинності КК України 2001 року.

Метою цієї роботи $є$ аналіз останніх підходів законодавця до корегування криміналізації порушення санітарних правил i норм щодо запобігання інфекційним хворобам та масовим отруєнням в контексті історії розвитку відповідної кримінальноправової заборони та визначення можливих шляхів вдосконалення правового регулювання в цій сфері з точки зору теоретичних підходів до криміналізації суспільно небезпечних діянь та законодавчої техніки.

Проблеми криміналізації суспільно небезпечних діянь, а також вдосконалення техніки законотворення у сфері кримінального права, не зважаючи на те, що вони досить детально піддані аналізу у роботах I.M. Гальперіна, О.А. Герцензона, П.Ф. Гришаніна, П.С. Дагеля, Ю.А. Демидова, М.I. Загороднікова, Г.А. Злобіна, I.I. Карпеця, В.Й. Квашиса, С.Г. Келіної, М.І. Ковальова, В.С. Комісарова, О.І. Коробєєва, В.М. Кудрявцева, Н.Ф. Кузнецової, Д.О. Балобанової, Ю.В. Бауліна, В.І. Борисова, В.К. Грищука, О.М. Костенка, О.М. Аитвака, М.І. Мельника, В.О. Меркулової, А.А. Митрофанова, В.О. Навроцького, В.В. Сташиса, В.Я. Тація, В.О. Тулякова, П.Л. Фріса, M.I. Хавронюка, B.I. Шакуна та інших вчених, залишаються актуальними.

Зокрема, пунктом 3 Розділу I Закону України від 17 березня 2020 року № 530-IX «Про внесення змін до деяких законодавчих актів України, спрямованих на запобігання виникненню і поширенню коронавірусної хвороби (COVID-19) [2] ${ }^{1} »$, статтю 325 Кримінального кодексу України було викладено в новій редакції․

\footnotetext{
${ }^{1}$ Про внесення змін до деяких законодавчих актів України, спрямованих на запобігання виникненню і поширенню коронавірусної хвороби (COVID-19) : Закон України від 17 березня 2020 року № 530. URL: https://zakon.rada.gov.ua/laws/show/530-20 (дата звернення: 14.04.2020)

${ }^{2}$ Стаття 325. Порушення санітарних правил і норм щодо запобігання інфекційним хворобам та масовим отруєнням
}

32001 року по квітень 2009 року стаття 325 КК мала наступний вигляд:

«Стаття 325. Порушення правил боротьби з епідеміями

Порушення правил, встановлених з метою запобігання епідемічним та іншим заразним захворюванням і боротьби з ними, якщо ці дії спричинили або завідомо могли спричинити поширення цих захворювань,

карається штрафом до п'ятдесяти неоподатковуваних мінімумів доходів громадян або арештом на строк до шести місяців, або обмеженням волі на строк до трьох років».

Згодом, до статті були внесені зміни Законом України від 17.03.2009 року №1125 [3], суб'єктом права законодавчої ініціативи щодо якого виступив Уряд. Суть змін полягала у криміналізації порушення правил протидії та боротьби не лише із заразними хворобами (які отримали формулювання «епідемічні та інші інфекційні»), але iз 3 неінфекційними масовими отруєннями. Крім того, до статті додали частину другу із кваліфікуючою ознакою «загибель людей чи інші тяжкі наслідки»³.

1. Порушення правил та норм, встановлених з метою запобігання епідемічним та іншим інфекційним хворобам, а також масовим неінфекційним захворюванням (отруєнням) і боротьби з ними, якщо такі дії спричинили або завідомо могли спричинити поширення цих захворювань, -

карається штрафом від тисячі до трьох тисяч неоподатковуваних мінімумів доходів громадян або арештом на строк до шести місяців, або обмеженням волі на строк до трьох років, або позбавленням волі на той самий строк.

2. Ті самі діяння, якщо вони спричинили загибель людей чи інші тяжкі наслідки, -

караються позбавленням волі на строк від п'яти до восьми років.

${ }^{3}$ В результаті, норма отримала такий вигляд:

«Стаття 325. Порушення санітарних правил i норм щодо запобігання інфекційним захворюванням та масовим отруєнням

1. Порушення правил та норм, встановлених 3 метою запобігання епідемічним та іншим інфекційним захворюванням, а також масовим неінфекційним захворюванням (отруєнням) і боротьби з ними, якщо такі дії спричинили або завідомо могли спричинити поширення цих захворювань, -

карається штрафом до ста неоподатковуваних мінімумів доходів громадян або арештом на строк 
Слід зауважити, що ця ідея станом на 2009 рік не була новою. Аналогічна за змістом законодавча пропозиція (Законопроект реєстр. №3623) надходила від попереднього Уряду до парламенту V скликання. Цей законопроект (№3623) було розроблено на виконання Постанови Верховної Ради України №3339 від 12 січня 2006 року [4], якою, серед іншого, за результатами констатації незадовільного стану справ у цій сфері ${ }^{4}$, парламентом Уряду було рекомендовано підготувати та внести на розгляд парламенту проекти законів, зокрема «щодо посилення юридичної відповідальності за діяння, які внаслідок порушення вимог санітарних і протиепідемічних норм та правил призвели до реальної загрози життю і здоров'ю людей чи до їх смерті, до виникнення масових інфекційних захворювань чи інших тяжких наслідків».

до шести місяців, або обмеженням волі на строк до трьох років.

2. Ті самі діяння, якщо вони спричинили загибель людей чи інші тяжкі наслідки, -

караються позбавленням волі на строк від п'яти до восьми років».

4 «Верховна Рада України відзначає, що захворюваність на інфекційні хвороби в Україні залишається високою і за багатьма нозологічними формами іiі рівень перевищує аналогічні показники країн EC. Щорічно реєструються групові випадки інфекційних захворювань і харчових отруєнь, масштабного поширення набули вірусні гепатити, крапельні та зоонозні інфекції, гельмінтози. Значну епідемічну небезпеку для населення України становлять так звані «екзотичні» інфекції, до яких належать малярія, атипова пневмонія (SARS), коров'ячий сказ, пташиний грип.

Украй занедбаною є матеріально-технічна база інфекційних лікарень та діагностичних лабораторій, в Україні випускається дуже мало вакцин, сироваток, діагностикумів, інших імунобіологічних препаратів, що становить реальну загрозу для національної безпеки держави.

Багато керівників органів виконавчої влади та органів місцевого самоврядування неналежно виконують визначені законами обов'язки щодо забезпечення санітарного та епідемічного благополуччя населення, що полягають у забезпеченні якісною питною водою та безпечними харчовими продуктами, прибиранні відходів і боротьбі з живими переносниками інфекційних хвороб, утриманні в чистоті відкритих водойм, територій населених пунктів, громадських місць і місць масового відпочинку тощо»
Внаслідок позачергових виборів до парламенту цей законопроект як не прийнятий за основу, отримав статус відкликаного, та знову був направлений до парламенту вже іншим Урядом через декілька місяців, навесні 2008 року.

В Пояснювальній записці до законопроекту реєстр. №2210, Уряд зазначав: схвалення проекту Закону України “Про внесення змін до Кримінального Кодексу України" дозволить посилити юридичну відповідальність за діяння, які в наслідок порушення вимог санітарних і протиепідемічних норм та правил призвели до реальної загрози життю і здоров'ю людей чи до їх смерті, до виникнення масових інфекційних захворювань чи інших тяжких наслідків.

Головне науково-експертне управління Апарату Верховної Ради України висловило до законопроекту одне зауваження: «покарання у виді обмеження волі або позбавлення волі на строк до п'яти років (ч. 2 пропонованої редакції ст. 325 КК) явно не відповідає досить високому ступеню, а також характеру суспільної небезпеки такого діяння, як порушення відповідних правил, яке спричинило поширення заразних захворювань і загибель унаслідок цього багатьох людей.

На це вказує, зокрема, співвідношення санкцій пропонованої норми і частини 2 ст. 119 КК України, яка передбачає, що вбивство двох або більше осіб, вчинене через необережність, карається позбавленням волі на строк від п'яти до восьми років. Тому ч. 2 ст. 325 потребує внесення відповідних коректив».

На нашу думку [5; 124], окрім цього, вартувало також привести термінологію статті КК у відповідність до галузевого законодавства та не поєднувати в диспозиції однієї частини статті делікт створення небезпеки та матеріальний склад злочину із реальними наслідками у вигляді виникнення чи поширення захворювань. Така практика не $є$ поширеною в кримінальному законодавстві України і це можна пояснити різницею у суспільній небезпеці діяння, яке могло призвести до поширення інфекції, та діяння, яке його реально спричинило. 


\section{Кримінальне право, кримінальний процес та криміналістика}

Так чи інакше, законопроект було ухвалено за основу та в цілому як закон без розгляду у другому читанні.

Зміни, внесені до редакції статті 325 КК у 2020 році полягають лише у: використанні терміну «інфекційні хвороби» замість «інфекційні захворювання» у диспозиції частини першої, а також у підвищенні розміру штрафу та введенні позбавлення волі на строк до трьох років до переліку покарань у санкції цієї ж частини першої.

Як справедливо зазначає Н. Гунько, насамперед прийоми юридичного конструювання мають забезпечувати формування та виклад нормативно-правового припису (логічно і граматично завершеного судження) відповідно до юридичної конструкції (засобу) «склад злочину» 3 урахуванням структури норм кримінального права, а також з урахуванням основних змістовних та формальних вимог щодо закону і, зокрема, кодифікованого [6; 7]. Відповідно, розглянемо з цієї точки зору правові наслідки зміни терміну «інфекційні захворювання» на «інфекційні хвороби» в диспозиції частини першої статті 325 КК.

Конституційний Суд доволі чітко зазначив: кримінальний закон, який визначає діяння як злочин, може містити посилання на положення інших нормативно-правових актів. Якщо ці положення в наступному змінюються, загальний зміст кримінального закону, в даному випадку - диспозиція його норм, змін не зазнає. Протилежне означало 6 можливість зміни кримінального закону підзаконними актами, зокрема постановами Верховної Ради України, указами Президента України та актами Кабінету Міністрів України, що суперечило б вимогам пункту 22 частини першої статті 92 Конституції України. ... Зміна мінімального розміру заробітної плати відповідним нормативно-правовим актом не тягне за собою зміни диспозиції, зміст якої визначається із застосуванням такого розміру. Такий закон - в даному разі частини четверті статей $81,82,84$, частина третя статті 83, частина друга статті 86 та стаття 86-1 Кодексу - не може вважатись новим і до нього не повинні застосовуватись положення частини першої статті 58 Конституції України та частини другої статті 6 Кодексу [7].
Проте, чи дає ця правова позиція Конституційного Суду відповіді на всі питання, які виникають у зв'язку із застосуванням на практиці бланкетних диспозицій кримінального закону? Очевидно, ні. I це підтверджується, зокрема останніми кримінально-правовими дослідженнями. Так, 3. Загиней-Заболотенко, аналізуючи проблеми визначеності кримінального законодавства підкреслює, що регулювання відповідного порядку суспільних відносин нормами інших галузей права може бути неповним, що зумовлює фактичну невизначеність кримінально-правових норм [8; 75]. Таким чином, якщо законодавець змінив термін «захворювання» на «хвороба»у тексті частини першої статті 325 КК, це повинно мати під собою підстави, що випливають зі змісту галузевого законодавства.

Окрім того, виникає питання щодо того, чи відноситься поняття «ці захворювання» до використаного раніше по тексту статті поняття «хвороба». Воно постало внаслідок змін, внесених Законом №530, і зауважимо, що у Пояснювальній записці до відповідного законопроекту [9] $]^{5}$ було зазначено лише про «підвищення кримінальної відповідальності за порушення санітарних правил і норм щодо запобігання інфекційним захворюванням», і жодного слова про зміну термінології, а, отже, і змісту кримінально-правової заборони. Це пояснюється тим, що автори законопроекту і не пропонували змінювати диспозицію статті 325 КК, лише санкцію.

Не дає відповіді на це питання і стенограма розгляду законопроекту на пленарному засіданні Верховної Ради України 17 березня 2020 року [10]. Жодним чином саме формулювання диспозиції статті 325 КК не обговорювалося. Отже, виникають серозні сумніви щодо підстав та процедури внесення змін до цієї норми КК в частині заміни слова «захворювання»на «хвороби».

\footnotetext{
${ }^{5}$ Про внесення змін до деяких законодавчих актів України, спрямованих на запобігання виникнення і поширення коронавірусної хвороби (COVID-19) : Проект Закону України від 16 березня 2020 року №3219. URL : http://w1.c1.rada.gov.ua/pls/zweb2/ webproc4_1?pf3511=68397 (дата звернення: 14.04.2020)
} 
Тим не менше, звернемося до галузевого законодавства 3 метою визначення понять, які потрібні для кримінально-правової кваліфікації за цією нормою, диспозиція якої носить відверто бланкетний характер.

Основи законодавства про охорону здоров'я оперують обома термінами: «хвороба» та «захворювання» ${ }^{6}$. У свою чергу, відповідно до Основ, здоров'я - це стан повного фізичного, психічного і соціального благополуччя, а не тільки відсутність хвороб і фізичних вад (ст. 3)

Особливий інтерес становить у цьому контексті стаття 30 Основ, яка стосується запобігання інфекційним захворюванням, небезпечним для населення ${ }^{8}$ В цій нормі в

\footnotetext{
6 Зокрема, поняття «захворювання» зустрічається в таких випадках: рідкісне (орфанне) захворювання - захворювання, яке загрожує життю людини або яке хронічно прогресує, призводить до скорочення тривалості життя громадянина або до його інвалідності, поширеність якого серед населення не частіше ніж 1:2000 (ст. 3); «ВІЛ-інфекції/СНІДу та інших соціально небезпечних захворювань» (ст. $15)$; професійні захворювання (ст. 28); спадкові захворювання (ст. 29); хронічні захворювання (ст. 322); невиліковні захворювання (ст. 354); рецидив захворювання, гострий період захворювання (ст. 355); соціально-небезпечні захворювання (туберкульоз, психічні, венеричні захворювання, СНІД, лепра, хронічний алкоголізм, наркоманія), а також карантинні захворювання (ст. 53); епідемічні захворювання (ст. 54).

${ }^{7}$ Крім того, на період хвороби з тимчасовою втратою працездатності громадянам надається звільнення від роботи з виплатою у встановленому законодавством України порядку допомоги по соціальному страхуванню (ст. 41).

${ }^{8}$ Стаття 30. Запобігання інфекційним захворюванням, небезпечним для населення

Держава забезпечує планомірне науково обгрунтоване попередження, лікування, локалізацію та ліквідацію масових інфекційних захворювань.

Особи, які є носіями збудників інфекційних захворювань, небезпечних для населення, усуваються від роботи та іншої діяльності, яка може сприяти поширенню інфекційних хвороб, і підлягають медичному нагляду і лікуванню за рахунок держави з виплатою в разі потреби допомоги по соціальному страхуванню. Щодо окремих особливо небезпечних інфекційних захворювань можуть здійснюватися обов'язкові медичні огляди, профілактичні щеплення, лікувальні та карантинні заходи в порядку, встановленому законами України.

У разі загрози виникнення або поширення епідемічних захворювань Кабінетом Міністрів України у
}

одній частині статті послідовно використовуються обидва терміни.

Закон України «Про протидію захворюванню на туберкульоз» [11] визначає правові, організаційні та фінансові засади діяльності, спрямованої на протидію виникненню і поширенню захворювання на туберкульоз, забезпечення медичної допомоги хворим на туберкульоз, і встановлює права, обов'язки та відповідальність юридичних і фізичних осіб у сфері протидії захворюванню на туберкульоз. Якщо врахувати, що цей же закон визначає туберкульоз як соціально небезпечну інфекційну хворобу, що викликається мікобактеріями туберкульозу, то згаданий закон покликаний протидіяти захворюванню на конкретну інфекційну хворобу.

Положення Закону України «Про забезпечення санітарного та епідемічного благополуччя населення» (далі - Закон №4004) [12] «не поширюються на харчові продукти, крім харчових продуктів, щодо яких проводяться санітарно-епідеміологічні розслідування захворювань, спричинених інбекційними хворобами, масовими неінфекційними захворюваннями, отруєннями та радіаційним ураженням людей» (ст. 1). Цей же Закон у статті 27 регламентує проведення профілактичних щеплень для запобігання поширенню інших інфекиійних захворювань (також ией термін зустрічається у статmі 40), а у статті 28 - і про інфекиійні захворювання $і$ про інфекційні хворобия. Крім

порядку, встановленому законом можуть запроваджуватися особливі умови і режими праці, навчання, пересування і перевезення на всій території України або в окремих їі місцевостях, спрямовані на запобігання поширенню та ліквідацію цих захворювань.

Місцеві державні адміністрації та органи місцевого самоврядування зобов'язані активно сприяти здійсненню протиепідемічних заходів.

Перелік особливо небезпечних і небезпечних інфекційних захворювань та умови визнання особи інфекційно хворою або носієм збудника інфекційного захворювання визначаються центральним органом виконавчої влади, що забезпечує формування державної політики у сфері охорони здоров'я i публікуються в офіційних джерелах

9 Стаття 28. Госпіталізація та лікування інфекційних хворих і носіїв збудників інфекційних хвороб

Особи, які хворіють особливо небезпечними та 


\section{Кримінальне право, кримінальний процес та криміналістика}

того, Закон використовує формулювання «особливо небезпечні і небезпечні інфекційні хвороби, масові неінфекційні захворювання (отруєння) або радіаційні ураження» (ст. 30), але не містить переліку епідемічних хвороб (захворювань).

Закон України «Про захист населення від інфекційних хвороб» (далі - Закон №1645) [13] оперує конструкцією «захворювання людей на інфекційні хвороби», яка може давати певні підстави для розмежування хвороб та захворювань. Можна (з урахуванням поняття «здоров'я», яке містять Основи) інтерпретувати так, що захворювання - це погіршення здоров'я людини внаслідок розвитку хвороби ${ }^{10}$.

небезпечними інфекційними хворобами або є носіями збудників цих хвороб, відсторонюються від роботи та іншої діяльності, якщо вона може призвести до поширення цих хвороб. Вони підлягають медичному нагляду і лікуванню за рахунок держави з виплатою допомоги з коштів соціального страхування в порядку, що встановлюється законодавством. Такі особи визнаються тимчасово чи постійно непридатними за станом здоров'я до професійної або іншої діяльності, внаслідок якої може створюватися підвищена небезпека для оточуючих у зв'язку з особливостями виробництва або виконуваної роботи.

Особи, хворі на особливо небезпечні інфекційні хвороби, в разі відмови від госпіталізації підлягають примусовому стаціонарному лікуванню, а носії збудників зазначених хвороб та особи, які мали контакт з такими хворими, обов'язковому медичному нагляду і карантину у встановленому порядку.

Перелік особливо небезпечних і небезпечних інфекційних захворювань, умови визнання особи хворою на інфекційну хворобу або носієм збудника інфекційної хвороби, протиепідемічні і карантинні правила встановлюються в порядку, визначеному законодавством.

${ }^{10}$ Цей же Закон у статті 1 визначає, що

інфекційні хвороби - розлади здоров'я людей, що викликаються живими збудниками (вірусами, бактеріями, рикетсіями, найпростішими, грибками, гельмінтами, кліщами, іншими патогенними паразитами), продуктами їх життедіяльності (токсинами), патогенними білками (пріонами), передаються від заражених осіб здоровим і схильні до масового поширення;

небезпечні інфекційні хвороби - інфекційні хвороби, що характеризуються важкими та (або) стійкими розладами здоров'я в окремих хворих і становлять небезпеку для їх життя та здоров'я;

особливо небезпечні інфекційні хвороби - інфекційні хвороби (у тому числі карантинні: чума, холера, жовта гарячка), що характеризуються важкими
Втім, це не дає відповіді на питання про те, що змінилося у складі злочину, передбаченого статтею 325 КК внаслідок зміни терміну «інфекційне захворювання» на термін «інфекційна хвороба».

Більше того, підзаконні нормативноправові акти так само, як і акти рівня закону оперують поняттями про інфекційні «захворювання» та «хвороби» як синонімами. Так, Наказом МОЗ від 19.07.1995 року №133 (із змінами) [14] затверджено (із прямим відсиланням до статті 28 Закону «Про забезпечення санітарного та епідемічного благополуччя населення» в назві) Перелік особливо небезпечних, небезпечних інфекційних та паразитарних хвороб людини і носійства збудників цих хвороб, серед яких, наприклад, є вірусні гепатити, кір та COVID-19. В той же час, Перелік інфекційних захворювань, які мають прогресивно/ поступово охоплюватися епідеміологічним наглядом, затверджений Наказом МО3 від 13.04.2016 року № 362 [15], серед інфекційних захворювань називає, серед інших, той самий кір та вірусні гепатити.

Таким чином, в контексті формулювання диспозиції частини першої статті 325 КК, слід зауважити, що галузеве законодавство не дає підстав для чіткого розмежування понять «інфекційне захворювання» та «інфекційна хвороба».

у свою чергу, масові неінфекційні захворювання (отруєння) - це масові захворювання, виникнення яких зумовлено впливом біологічних, фізичних, хімічних чи соціальних факторів середовища життедіяльності, у тому числі об'єктів господарської та інших видів діяльності, продукції, робіт, послуг (ст. 1 Закону «Про забезпечення санітарного та епідемічного благополуччя населення»).

Відповідно до статті 28 закону України «Про захист населення від інфекційних хвороб», ввезення на територію України товарів не допускається у разі, якщо

та (або) стійкими розладами здоров'я у значної кількості хворих, високим рівнем смертності, швидким поширенням цих хвороб серед населення;

епідемія - масове поширення інфекційної хвороби серед населення відповідної території за короткий проміжок часу. 
їх ввезення: заборонено законодавством у зв'язку з небезпекою для життя і здоров'я людей; може спричинити масові інфекційні захворювання або отруєння людей.

В той же час, використання в тексті кримінального закону в одній його нормі понять «інфекційна хвороба» та «масові неінфекційні захворювання (отруєння)», не сприяє підвищенню правової визначеності, оскільки заміна законодавцем «захворювання» на термін «хвороба» ставить питання про наявність/відсутність різниці в цих поняттях. Адже у вироку має бути чітко зазначено, правила запобігання якій конкретно інфекційній хворобі (раніше - інфекційному захворюванню) порушив винний. I враховуючи, що галузеве законодавство містить перелік інфекційних хвороб, який відрізняється від переліку інфекційних захворювань (наприклад, грип є серед переліку інфекційних захворювань, але відсутній у переліку хвороб), треба зробити висновок, що обсяг криміналізації певним чином змінився.

Ще одне питання, яке виникає в контексті зазначеної кримінально-правової норми, це наслідок як ознака об'єктивної сторони складу злочину («якщо такі дії спричинили або завідомо могли спричинити поширення цих захворювань»). До заміни терміну «інфекційні захворювання» на «інфекційні хвороби» словосполучення «цих захворювань» відносилося як до інфекційних захворювань, так і до неінфекційних захворювань. Після появи в тексті статті терміну «інфекційні хвороби», постає питання, чи варто продовжувати тлумачити цю норму так, що вказаний наслідок відноситься як і раніше до всіх форм об'єктивної сторони, проте, якщо відповісти стверджувально, то це не буде буквальним тлумаченням. 3 іншого боку, якщо не поширювати наслідок на таку форму об'єктивної сторони, як «порушення правил та норм, встановлених 3 метою запобігання епідемічним та іншим інфекційним хворобам», то такий склад злочину набуває ознак формального, що, у свою чергу, навряд чи виправдано і не дозволяє говорити про наявність необхідного для криміналізації рівня суспільної шкідливос- ті виключно у випадку порушення певних правил, без жодних наслідків.

Очевидно, що цей злочин в усіх його формах має бути сконструйований із матеріальним складом. Одним із варіантів вирішення цього питання (за умови залишення в диспозиції обох термінів) буде формулювання наслідків у частині першій статті 325 наступним чином: «якщо такі дії спричинили або завідомо могли спричинити поширення цих хвороб або захворювань».

Тепер проаналізуємо, в чому полягають та чим закріплені правила та норми, встановлені з метою запобігання епідемічним та іншим інфекційним хворобам, а також масовим неінфекційним захворюванням (отруєнням) і боротьби з ними. Отже, за рівнем закріплення це можуть буди положення: законів; Підзаконних нормативно-правових актів; рішень суб'єктів протидії виникненню чи поширенню хвороб, які часто мають обмежену у часі та просторі дію. При цьому, варто розрізняти масив норм, правил, вимог тощо, які сприяють профілактиці, попередженню відповідних захворювань, та норм, спрямованих на протидію їх поширенню вже після спалаху.

Відповідно до Закону «Про захист населення від інфекційниї хвороб» відносини у сфері захисту населення від інфекційних хвороб регулюються Основами законодавства України про охорону здоров'я, законами України «Про забезпечення санітарного та епідемічного благополуччя населення», «Про запобігання захворюванню на синдром набутого імунодефіциту (СНІД) та соціальний захист населення», цим Законом, іншими нормативно-правовими актами. Це фактично, з огляду на назву цієї норми, законодавство про захист населення від інфекиійних хвороб. Зауважимо, що існує також «законодавство України про забезпечення санітарного та епідемічного благополучия населення» ${ }^{11}$. Крім того, громадяни

11 Відповідно до Закону №4004, законодавство України про забезпечення санітарного та епідемічного благополуччя населення (санітарне законодавство) базується на Конституції України і складається з Основ законодавства України про охорону здоров’я, цього Закону, законів України «Про захист населення від інфекційних хвороб», «Про про- 


\section{Кримінальне право, кримінальний процес та криміналістика}

зобов'язані, серед іншого, виконувати інші обов'язки, передбачені законодавством про забезпечення санітарного та епідемічного благополучия ${ }^{12}$. Відповідно до статті 49 Закону №4004, діяння проти здоров’я населення, вчинені внаслідок порушення санітарного законодавства, тягнуть за собою кримінальну відповідальність згідно з законом.

Закон №1645 визначає, що центральний орган виконавчої влади, що забезпечує формування державної політики у сфері охорони здоров'я, щодо захисту населення від інфекційних хвороб затверджує санітарно-протиепідемічні правила $i$ норми, методи обстеження та лікування хворих, діагностики та профілактики інфекційних хвороб, інші нормативно-правові акти.

У свою чергу, центральний орган виконавчої влади, що реалізує державну політику у сфері санітарного та епідемічного благополуччя населення, щодо захисту населення від інфекційних хвороб: розробляє санітарні норми, методи профілактики інфекційних хвороб, інші нормативно-правові акти; здійснює нагляд за додержанням підприємствами, установами, організаціями незалежно від форми власності та громадянами законодавства у сбері захисту населення від інфекиійних хвороб, контролюе виконання вимог санітарно-протиепідемічних правил і норм.

Крім того, треба взяти до уваги, що одним із «основних принципів профілактики інфекційних хвороб» 6 :

... дотримання підприємствами, установами, організаціями незалежно від форм власності та громадянами санітарно-гігієнічних та санітарно-протиепідемічних правил $i$ норм при здійсненні будь-яких видів діяльності;

Закон України «Про забезпечення санітарного та епідемічного благополуччя населення» визначає, що державні санітарні норми та правила, санітарно-гігієнічні та санітарно-протиепідемічні правила і нор-

тидію захворюванню на туберкульоз», «Про запобігання захворюванню на синдром набутого імунодефіциту (СНІД) та соціальний захист населення», інших нормативно-правових актів та санітарних норм».

${ }^{12}$ Стаття 5 Закону №4004. ми, санітарно-епідеміологічні правила i норми, протиепідемічні правила і норми, гігієнічні та протиепідемічні правила i норми, державні санітарно-епідеміологічні нормативи, санітарні регламенти (далі - санітарні норми) - обов'язкові для виконання нормативно-правові акти центрального органу виконавчої влади, що забезпечує формування державної політики у сфері охорони здоров'я, що встановлюють медичні вимоги безпеки щодо середовища життедіяльності та окремих його бакторів, недотримання яких створюе загрозу здоров'ю і життю людини та майбутніх поколінь, а також загрозу виникнення $i$ розповсюдження інфекиійних хвороб та масових неінфекиійних захворювань (отруєнь) серед населення.

Термін «боротьба» цей Закон не використовує, а у Законі «Про захист населення від інфекційних хвороб» він зустрічається тричі, проте, як видається, він стосується декількох ситуацій практичного характеру i не $є$ вдалим інструментом для опису того, які саме правила заборонено порушувати.

Коректніше, на наш погляд, казати $n p o$ правила, спрямовані на запобігання виникненню та/або поширенню інфекційних хвороб чи масових неінфекиійних захворювань (отруєнь).

Необхідність формулювання на рівні кримінального закону певного узагальнюючого поняття обумовлена тим, що галузеве законодавство містить розгалужену систему норм, правил, обов'язків різних суб'єктів правовідносин у сфері запобігання та протидії поширенню інфекційних та окремих неінфекційних захворювань.

Наприклад, до повноважень місцевих органів виконавчої влади у сфері захисту населення від інфекційних хвороб віднесено здійснення контролю за додержанням юридичними і фізичними особами санітарно-гігієнічних, санітарно-протиепідемічних та ветеринарних правил і норм, правил торгівлі та побутового обслуговування населення. Це достатньо широке коло норм і виникає питання, чи, скажімо, можна віднести правила побутового обслуговування населення до правил та норм, встановлених саме з метою запобігання епідемічним та іншим інбекиійним хворобам, як цього вимагає чинна редакція статті 325 КК. 
Очевидно, що існує дуже багато різного роду правил ведення господарської та іншої діяльності, порушення яких може призвести до поширення інфекційних хвороб, але чи є вони правилами, встановленими з метою запобігання епідемічним та іншим інфекційним хворобам?

Так, пункт 6 Глави 9 «入ісоматеріали та будівельні матеріали» Правил роздрібної торгівлі непродовольчими товарами [16] встановлює наступне: усі лісоматеріали та будівельні матеріали перед складанням ретельно перевіряються для того, щоб не допустити занесення до місць зберігання різноманітних грибків та шкідників. В обов'язковому порядку вживаються заходи з боротьби із шкідливими комахами та гризунами, а також з дезінфекції приміщень.

Це очевидна норма, що сприяє профілактиці поширення інфекцій, але чи робить вона ці правила такими, що встановлені з метою запобігання епідемічним та іншим інфекційним хворобам? I якщо таким правилом 6 не весь акт, а лише ця норма, то яким чином визначити в кожному конкретному випадку, що було порушено саме правило, зазначене у КК? Чи робить сам факт, що порушення якогось правила призвело до поширення інфекції, це правило таким, що встановлено ... і далі за текстом?

Загалом, механізм протидії таким захворюванням (хворобам) полягає у встановленні та дотриманні певного режиму для запобігання виникненню та/або поширенню захворювання, а також у вжитті спеціалізованих заходів, в тому числі тимчасового нормативно-правового характеру, метою яких $\epsilon$ протидія захворюванню, яке виникло і поширюється.

Зокрема, санітарно-протиепідемічні правила і норми - це нормативно-правові акти (накази, інструкції, правила, положення тощо) центрального органу виконавчої влади, що забезпечує формування державної політики у сфері охорони здоров'я, вимоги яких спрямовані на запобігання виникненню та поширенню інфекційних хвороб;

Доволі часто галузеве законодавство оперує поняттям, «адміністративні заходи», яке, очевидно, охоплює випадки встановлення правил, обмежень, вимог тощо і $є$ по суті різновидом правотворчості, яка визначає зміст кримінально-правової норми. Наприклад, обмежувальні протиепідемічні заходи - це медико-санітарні та адміністративні заходи, що здійснюються в межах осередку інфекційної хвороби з метою запобігання іії поширенню. Також, протиепідемічні заходи - це комплекс організаційних, медико-санітарних, ветеринарних, інженерно-технічних, адміністративних та інших заходів, що здійснюються 3 метою запобігання поширенню інфекційних хвороб, локалізації та ліквідації їх осередків, спалахів та епідемій. У свою чергу, карантин - це адміністративні та медико-санітарні заходи, що застосовуються для запобігання поширенню особливо небезпечних інфекційних хвороб ${ }^{13}$.

Закон «Про захист населення від інфекційних хвороб» містить окремі прямі норм зобов'язуючого характеру ${ }^{14}$, а також уповноважує низку суб'єктів на встановлення певних тимчасових правил ${ }^{15}$.

Так, особи, які хворіють на інфекційні хвороби чи є бактеріоносіями, зобов'язані: вживати рекомендованих медичними працівниками заходів для запобігання поширенню інфекційних хвороб; виконувати вимоги та рекомендації медичних працівників щодо порядку та умов лікування, додержуватися режиму роботи закладів охорони здоров'я та наукових установ, у яких вони лікуються; проходити у встановлені строки необхідні медичні огляди та обстеження (стаття 20).

В цьому випадку, якщо внаслідок порушення цього обов'язку настали наслідки, визначені кримінальним законом, а також наявні інші ознаки складу злочину, можна говорити про можливість настання кримінальної відповідальності.

Інший приклад. У разі якщо бактеріоносіями $є$ особи, робота яких пов'язана 3 обслуговуванням населення і може призвести до поширення інфекційних хвороб, такі особи за їх згодою тимчасово перево-

\footnotetext{
${ }^{13}$ Стаття 1 Закону №1645.

14 Дітям, які не отримали профілактичних щеплень згідно з календарем щеплень, відвідування дитячих закладів не дозволяється (стаття 15).

${ }^{15}$ Стаття 30 Закону №1645.
} 


\section{Кримінальне право, кримінальний процес та криміналістика}

дяться на роботу, не пов'язану з ризиком поширення інфекційних хвороб. Якщо зазначених осіб перевести на іншу роботу неможливо, вони відсторонюються від роботи в порядку, встановленому законом. На період відсторонення від роботи цим особам виплачується допомога у зв'язку з тимчасовою втратою працездатності.

Зазначена норма встановлює обов'язок відповідної службової особи, тимчасово перевести бактеріоносія на роботу, не пов'язану з ризиком поширення інфекційних хвороб, а якщо зазначену особу перевести на іншу роботу неможливо, - відсторонити їі від роботи в порядку, встановленому законом. Проте, залишається відкритим питання про «порядок, встановлений законом».

Aле таких прикладів небагато. Так, викликає питання, чи наявний склад злочину у разі порушення наступної вимоги закону: особи, які хворіють на соціально небезпечні інфекційні хвороби, підлягають своєчасному та якісному лікуванню, періодичним обстеженням і медичному нагляду (стаття 24).

Актуальним прикладом зараз є питання реалізації режиму карантину. Відповідно до Закону ${ }^{16}$, у рішенні про встановлення карантину зазначаються обставини, що призвели до цього, визначаються межі території карантину, затверджуються необхідні профілактичні, протиепідемічні та інші заходи, їх виконавці та терміни проведення, встановлюються тимчасові обмеження прав фізичних і юридичних осіб та додаткові обов'язки, що покладаються на них, підстави та порядок обов'язкової самоізоляції, перебування особи в обсерваторі (обсервації), госпіталізації до тимчасових закладів охорони здоров'я (спеціалізованих шпиталів). На цей період можуть змінюватися режими роботи підприємств, установ, організацій, вноситися інші необхідні зміни щодо умов їх виробничої та іншої діяльності. Карантин встановлюється та відміняється Кабінетом Міністрів України. Організація та контроль за дотриманням встановленого на території карантину

\footnotetext{
${ }^{16}$ Стаття 29 Закону № 1645.
}

правового режиму, своєчасним і повним проведенням профілактичних і протиепідемічних заходів покладаються на місцеві органи виконавчої влади та органи місцевого самоврядування.

Обмежувальні протиепідемічні заходи встановлюються місцевими органами виконавчої влади та органами місцевого самоврядування за поданням відповідного головного державного санітарного лікаря у разі, коли в окремому населеному пункті, у дитячому виховному, навчальному чи оздоровчому закладі виник спалах інфекційної хвороби або склалася неблагополучна епідемічна ситуація, що загрожує поширенням інфекційних хвороб. Обмеженням підлягають ті види господарської та іншої діяльності, що можуть сприяти поширенню інфекційних хвороб.

Як ми бачимо, галузеве законодавство містить розгалужену систему норм у сфері запобігання виникненню та поширенню інфекційних хвороб та неінфекційних захворювань (отруєнь). В цьому контексті застосоване у КК формулювання «правила та норми, встановлені з метою запобігання епідемічним та іншим інфекційним хворобам, а також масовим неінфекційним захворюванням (отруєнням) і боротьби з ними» не дозволяє однозначно віднести ті чи інші правові норми до тих, порушення яких за необхідних умов тягне кримінальну відповідальність.

Важливим питанням тут також є порядок оприлюднення відповідних актів, які визначають зміст тієї чи іншої заборони. Як бачимо, це можуть бути рішення центральних або місцевих органів виконавчої влади, органів місцевого самоврядування тощо.

Наприклад, на територіях, де Урядом встановлено карантин, місцевим органам виконавчої влади та органам місцевого самоврядування надається право в тому числі установлювати особливий режим в’їду, виїзду на території карантину та окремих адміністративно-територіальних одиниць громадян і транспортних засобів, а у разі необхідності - проводити санітарний огляд речей, багажу, транспортних засобів та вантажів. 
Зокрема, Постанова №211 [17] містить чіткий перелік заборон, проте він постійно змінюється. В той же час, в умовах протидії спалаху коронавірусної хвороби з'явився цілий пласт норм, запроваджених в межах процедур протидії надзвичайним ситуаціям, які містять певні обмежені в дії у часі та просторі заборони чи зобов'язання. Це, наприклад, рішення Комісій з питань техногенно-екологічної безпеки та надзвичайних ситуацій. Так, 21 березня 2020 року у ЗМІ з'явилася інформація про те, що «У Києві заборонили користуватися дитячими та спортивними майданчиками у парках, скверах та на прибудинкових територіях». Відповідний протокол №16 Постійної комісії $з$ питань техногенно-екологічної безпеки та надзвичайних ситуацій КМДА [18] містить такий пункт: «Районним в місті Києві державним адміністраціям, комунальному об’єднанню Київзеленбуд, ГУ Національної поліції України у м. Києві забезпечити проведення інформачійної та роз'яснювальної роботи щодо заборони користування дитячими та спортивними майданчиками в парках, скверах та на прибудинкових територіях». Чи $є$ це норма чи правило, в сенсі статті 325 КК? Як видається, ні.

Нагадаємо, що відповідно до статті 68 Конституції, незнання законів не звільняє від юридичної відповідальності. Але чи відповідає цьому притягнення до відповідальності за порушення норми, встановленої органом місцевого самоврядування?

3 огляду на це, формулювання, використані у статті 325 КК, можуть значно ускладнити правозастосування, оскільки далеко не всі із цих норм (порушення яких на практиці може призвести до поширення інфекцій чи отруєнь) можна визначити як правила та норми, встановлених 3 метою запобігання епідемічним та іншим інфекційним хворобам, а також масовим неінфекційним захворюванням (отруєнням) i боротьби з ними.

На практиці сторона обвинувачення та суди схиляються в бік якомога ширшого переліку порушень, які в конкретному випадку призводять до захворювань.

Зокрема, до штрафу у 850 гривень було засуджено підприємця, що допустив по- рушення, які спричинили масове харчове отруєння осіб, які купували продукцію у кафе [19]. Причиною спалаху інфекційного захворювання стало вживання недоброякісних харчових продуктів - шаурми, збудником спалаху є Salmonellaenteretidis, яка виділена з терки готової продукції, фактором передачі якої була шаурма. У 88 осіб - 15 з яких звернулись з заявою про залучення як потерпілих, встановлено діагноз - сальмонельоз, фактором зараження яких являється вживання недоброякісних харчових продуктів (шаурми) заражених мікроорганізмами - Salmonellaenteretidis, яка відноситься до факультативних аеробних ентеробактерій. Суд зазначив, що згідно Наказу МОЗ України захворювання Сальмонельоз є небезпечною інфекційною хворобою. Також, у вироку зазначено, що за міжнародною класифікацією МКХ-10 має шифр А02 - інші сальмонельозні інфекції. Отже, суд дійшов висновку, що винний вчинив порушення правил та норм, встановлених з метою запобігання епідемічним та іншим інфекиійним захворюванням, а також масовим неінфекційним захворюванням (отруєнням) $і$ боротьби з ними, якщо такі дї спричинили поширення изих захворювань. При цьому, з вироку видно, що були порушені норми не лише Закону України «Про якість та безпеку харчових продуктів і продовольчої сировини», але й санітарні норми зберігання продукті, що швидко псуються, затверджені Головним санітарним лікарем СРСР у 1986 році, зокрема «допустив на роботу двох кухарів, в яких на той момент була відсутня медична книжка».

Отже, в реальності, коли трапляється масове отруєння, сторона обвинувачення викладає всі порушення будь-яких правил чи вимог, не встановлюючи, яке конкретно порушення призвело до настання наслідку. 3 кримінально-правової кваліфікації навіть не видно чітко, який склад злочину суд визнає вчиненим особою, фактично копіюючи всю диспозицію частини першої статті 325 КК.

В іншому схожому випадку суд послався на порушення норм виключно законів України та наказів МОЗ України, при цьому кваліфікував скоєне за сукупністю 


\section{Кримінальне право, кримінальний процес та криміналістика}

із службовою недбалістю [20]. Кінцеве покарання було визначене шляхом поглинення менш суворого покарання більш суворим покаранням, у вигляді штрафу у сумі 4250 грн. 00 коп. 3 позбавлення права обіймати певні посади, а саме: посади, пов'язані з організаційно - розпорядчими функціями на підприємствах усіх форм власності строком на 1 рік. В попередніх випадках до відповідальності було притягнуто фізичну особу-підприємця та адміністратора кафе. У іншому випадку - із шеф-кухарем комунального закладу «мізоцька спеціальна загальноосвітня школа - інтернат I-II ступенів» Рівненської обласної ради - суд визнав шеф-кухаря посадовою особою та при визначенні обсягу порушених правил навів положення відповідної посадової інструкції, проте не кваліфікував вчинене як службову недбалість [21].

На наш погляд, порушення санітарних норм можуть вчинятися як службовими особами, так і загальним суб'єктом злочину, тому в першому випадку варто кваліфікувати вчинене за сукупністю злочинів. Так, ознаки службової недбалості присутні в діях особи [22], яка, будучи фізичною особою підприємцем, під час виробництва овочевих закусок, в порушення вимог Закону України «Про забезпечення санітарного та епідеміологічного благополуччя населення», Закону України «Про безпечність та якість харчових продуктів», неналежно виконуючи санітарні правила та норми щодо запобігання інфекційним захворюванням та масовим отруєнням, реально усвідомлюючи, що ї̈ діяння могло завідомо спричинити поширення епідемічних та інших інфекиійних захворювань, а також масових не інбекиійним захворюванням (отруєнням) допустила виготовлення продуктів харчування в неналежних для виготовлення та зберіганнях умовах.

На нашу думку, при притягненні осіб до кримінальної відповідальності за статтею 325 КК треба враховувати, що не завжди склад злочину є виключно в діях однієї особи (директора чи адміністратора закладу). Цілком можливі ситуації, і це видно на вище наведених прикладах, коли санітарні норми порушуються як службовою особою, так і працівником.

Законодавця можна зрозуміти, адже неможливо перелічити всі можливі нормативно-правові акти, якими встановлені правила, норми чи вимоги, порушення яких може призвести до виникнення чи поширення інфекційних хвороб чи отруєнь.

Проте, формулювання в тексті кримінального закону має бути достатньо чітким i в той же час абстрактним, щоби: 1) не звужувати обсяг таких правил до того чи іншого нормативно-правового акту, що більше відповідає цьому визначенню за змістом чи назвою; 2) не вимагати від сторони обвинувачення доводити зайві обставини, наприклад, чи були певні правила прийняті саме 3 певною метою; 3) не давати можливості занадто широко тлумачити обсяг правил, порушення яких визначає зміст кримінально-правової норми.

Кримінальний закон достатньо часто використовуе конструкції бланкетного характеру, з посиланням на нормативні порядки, акти, закони чи законодавство ${ }^{17}$.

\footnotetext{
${ }^{17}$ Наприклад:

Умисні дії, вчинені з метою зміни меж території
} або державного кордону України на порушення порядку, встановленого Конституцією України, а також публічні заклики чи розповсюдження матеріалів із закликами до вчинення таких дій;

Умисне порушення встановленого законом порядку застосування трансплантації анатомічних матеріалів людини, що спричинило істотну шкоду здоров'ю потерпілого;

Порушення встановлених правил охорони надр, якщо це створило небезпеку для життя, здоров'я людей чи довкілля;

Порушення правил охорони вод (водних об'єктів), якщо це спричинило забруднення поверхневих чи підземних вод і водоносних горизонтів, джерел питних, лікувальних вод або зміну їхніх природних властивостей, або виснаження водних джерел і створило небезпеку для життя, здоров'я людей чи для довкілля;

Порушення правил, установлених для боротьби зі шкідниками і хворобами рослин, та інших вимог законодавства про захист рослин, що спричинило тяжкі наслідки;

Порушення правил полювання, якщо воно заподіяло істотну шкоду, а також незаконне полювання в заповідниках або на інших територіях та об'єктах природно-заповідного фонду, або полювання на звірів, птахів чи інші види тваринного світу, що занесені до Червоної книги України; 
3 урахуванням цього, а також проведеного вище аналізу, пропонується наступна редакція статті 325 КК:

Стаття 325. Порушення правил запобігання інфекиійним хворобам або масовим отруєнням

1. Порушення встановлених відповідно до закону правил запобігання виникненню або поширенню інфекиійних хвороб, масових неінбекизйних захворювань (отруєнь), якщо чуе порушення завідомо могло спричинити виникнення чи поширення изих хвороб або захворювань, -

карається итраббом від тисячі до трьох тисяи неоподатковуваних мінімумів доходів громадян або арештом на строк до шести місяиів, або обмеженням волі на строк до трьох років, або позбавленням волі на той самий строк.

2. Те саме діяння, якщо воно спричинило виникнення чи поширення інфекиійних хвороб, масових неінфекиійних захворювань (отруєнь), -

караються обмеженням волі на строк від трьох до п'яти років, або позбавленням волі на той самий строк.

3. Діяння, передбачені частинами першою або другою иієї статті, якщо вони спричинили загибель людей чи інші тяжкі наслідки, -

караються позбавленням волі на строк від n'яти до восьми років.

Це дозволить: 1) через конструкцію «встановлених відповідно до закону» охопити весь обсяг спеціальних правил, незалежно від того чи це законодавчі чи підзаконні акти, але тільки ті, що встановлені в межах визначеного законом порядку вжиття адміністративних чи інших заходів протидії виникненню чи поширенню відповідних хвороб; 2) позбавитись конструкції

Порушення встановлених законодавством вимог пожежної безпеки, якщо воно спричинило виникнення пожежі, якою заподіяно шкоду здоров'ю людей або майнову шкоду у великому розмірі;

Порушення вимог законодавчих та інших нормативно-правових актів про охорону праці службовою особою підприємства, установи, організації або громадянином - суб'єктом підприємницької діяльності, якщо це порушення заподіяло шкоду здоров'ю потерпілого;

Умисне порушення встановленого порядку доклінічного вивчення, клінічних випробувань лікарських засобів, фальсифікація їх результатів, а також порушення встановленого порядку державної реєстрації лікарських засобів. «спричинило або могло спричинити» як наслідку у матеріальному складі, визначеному в частині першій і відокремити делікт створення небезпеки (частина перша) від діяння, що призвело до реальних негативних наслідків (частина друга); 3) оптимізувати текст кримінально-правової норми, позбавивши його зайвого, наприклад, вказівки на «епідемічні та інші» інфекційні хвороби, адже галузеве законодавство термін «епідемічні інфекційні хвороби» не використовує, розрізняючи такі хвороби за ступенем небезпечності. Крім того, конструкція «епідемічні та інші...» 3 точки зору формальної логіки позбавлена сенсу, адже вона охоплює всі інфекційні хвороби.

Разом $з$ тим, окрему увагу треба приділити визначенню в галузевому законодавстві порядку оприлюднення підзаконних нормативно-правових актів та тимчасових рішень численних суб'єктів, що беруть участь у протидії виникненню або поширенню інфекційних хвороб та масових отруєнь.

Подальші дослідження в цьому контексті повинні стосуватися формування сталої практики застосування статті 325 КК, зокрема в частині визначення особливостей причиново-наслідкового зв'язку між порушенням спеціальних правил та наслідком у вигляді поширення або виникнення відповідного захворювання.

\section{Лiтература}

1. Копиленко О., Богачова О. Законотворчий процес: стан і шляхи вдосконалення. Наукові записки Інституту законодавства Верховної Ради України. 2010. №1. С. $5-14$.

2. Про внесення змін до деяких законодавчих актів України, спрямованих на запобігання виникненню і поширенню коронавірусної хвороби (COVID-19) : Закон України від 17 березня 2020 року № 530. URL: https://zakon.rada.gov.ua/laws/ show/530-20 (дата звернення: 05.05.2020).

3. Про внесення змін до статті 325 Кримінального кодексу України : Закон України від 17 березня 2009 року № 1125VI. URL : https://zakon.rada.gov.ua/laws/ show/1125-17 (дата звернення: 05.05.2020). 


\section{Кримінальне право, кримінальний процес та криміналістика}

4. Про інформацію Кабінету Міністрів України про стан захворюваності населення України на інфекційні хвороби та заходи щодо її зниження : Постанова Верховної Ради України від 12 січня 2006 року №3339-VI. URL : https://zakon.rada.gov.ua/ laws/show/3339-15/conv (дата звернення: 05.05.2020).

5. Швець В.Д., Грицак В.М., Василькевич Я.І., Гацелюк В.О. Законодавча реалізація кримінально-правової політики: аналіз законопроектної діяльності Верховної Ради України V скликання з питань кримінального права. Київ : Атіка, 2008. 244 с.

6. Гунько Н. Загальнотеоретична характеристика законодавчої техніки. Начиональный юридический журнал: теория и практика. 2019. Серпень. С. 5 - 8.

7. Рішення Конституційного Суду України у справі за конституційним поданням 46 народних депутатів України щодо офіційного тлумачення положень статті 58 Конституції України, статей 6, 81 Кримінального кодексу України (справа про зворотну дію кримінального закону в часі) від 19 квітня 2000 року №6-рп/2000 URL : https://zakon.rada.gov. ua/laws/show/v006p710-00 (дата звернення: 05.05.2020).

8. Загиней-Заболотенко 3. Невизначеність vs визначеність кримінального законодавства України. Право Украйни. 2020. №2. С. $67-80$.

9. Про внесення змін до деяких законодавчих актів України, спрямованих на запобігання виникнення і поширення коронавірусної хвороби (COVID-19) : Проект Закону України від 16 березня 2020 року №3219. URL : http://w1.cl.rada.gov.ua/ pls/zweb2/webproc4 1?pf3511=68397 (дата звернення: 05.05.2020).

10. Стенограма позачергового пленарного засідання Верховної ради України 17 березня 2020 року. URL : https://iportal. rada.gov.ua/meeting/stenogr/show/7392.html (дата звернення: 05.05.2020).

11. Про протидію захворюванню на туберкульоз : Закон України від 05 червня 2001 року №2586-III. URL : https://zakon. rada.gov.ua/laws/show/2586-14/conv (дата звернення: 05.05.2020).
12. Про забезпечення санітарного та епідемічного благополуччя населення : Закон України від 24 лютого 1994 року №4004-XII. URL : https://zakon.rada.gov. ua/laws/show/4004-12/conv (дата звернення: 05.05.2020).

13. Про захист населення від інфекційних хвороб : Закон України від 06 квітня 2000 року №1645-III. URL : https://zakon. rada.gov.ua/laws/show/1645-14 (дата звернення: 05.05.2020).

14. Про затвердження Переліку особливо небезпечних, небезпечних інфекційних та паразитарних хвороб людини і носійства збудників цих хвороб : Наказ МОЗ України від 19 липня 1995 року №133. URL : https://zakon.rada.gov.ua/rada/show/ v0133282-95/sp:max100/conv (дата звернення: 05.05.2020).

15. Про затвердження Переліку інфекційних захворювань : Наказ МОЗ України від 13 квітня 2016 року №362. URL : $\underline{\text { https:// }}$ zakon.rada.gov.ua/laws/show/z0714-16 (дата звернення: 05.05.2020).

16. Про затвердження Правил роздрібної торгівлі непродовольчими товарами : Наказ Міністерства економіки України від 19 квітня 2007 року №104. URL : https:// zakon.rada.gov.ua/laws/show/z1257-07 (дата звернення: 05.05.2020).

17. Про запобігання поширенню на території України гострої респіраторної хвороби COVID-19, спричиненої коронавірусом SARS-CoV-2 : Постанова Кабінету Міністрів України від 11 березня 2020 року №211. URL : https://zakon.rada.gov.ua/laws/ show/211-2020-\%D0\%BF (дата звернення: 05.05.2020).

18. Протокол № 16 Постійної комісії ТЕБ та НС «Про запобігання поширенню гострої респіраторної хвороби COVID-19, спричиненої короновірусом SARS-CoV-2, та введення додаткових обмежувальних заходів на території міста Києва» від 21 березня 2020 року. URL : https:// kyivcity.gov.ua/news/protokol_16_postiyno komisi_teb_ta_ns_pro_zapobigannya poshirennyu gostro respiratorno khvorobi COVID-19_sprichineno_koronovirusom SARS-CoV-2 ta vvedennya dodatkovikh_ obmezhuvalnikh_zakhodiv_na_teritori 
Гацелюк В.О. - Проблеми визначення змісту та обсягу криміналізації порушення...

\section{АНОТАЦІЯ}

Стаття присвячена аналізу змісту та обсягу криміналізащї̈ порушення правил $і$ норм щзодо запобігання інфекиійним хворобам та масовим отруєнням з урахуванням рішень законодавия, ухвалених з метою протидій коронавірусній хворобі (COVID-19). На підставі аналізу законодавства про протидію інфекиійним захворюванням зроблено висновок про доизільність використання у тексті диспозииій статті 325 Кримінального кодексу формулювання «правила, спрямовані на запобігання виникненню та/або поширенню інфекиійних хвороб чи масових неінфекиійних захворювань (отруєнь)». На підставі аналізу чинних норм кримінального законодавства та наукових позичій запропоновано можливий шлях вдосконалення кримінального права у иъому сегменті шляхом викладення статті 325 у новій редакиї.

Ключові слова: криміналізачія, інфекиійна хвороба, отруєння; склад злочину.

mista_kiyeva_401359/__дата звернення: 05.05.2020).

19. Вирок Ізмаїльського міськрайонного суду Одеської області від 10 січня 2018 року. URL : http://reyestr.court. gov.ua/Review/71493337 (дата звернення: 05.05.2020).

20. Вирок Саксаганського районного суду м. Кривого Рогу Дніпропетровської області від 10 вересня 2014 року. URL :

\section{SUMMARY}

The article is devoted to the analysis of the content and extent of criminalization of violations of the rules and norms for the prevention of infectious diseases and mass poisoning, taking into account the decisions of the legislator, adopted in order to counteract coronavirus disease (COVID-19). Based on the analysis of the legislation on combating infectious diseases, the conclusion is made about the expediency of use in the text of the Article 325 of the Criminall Code, wording «rules aimed at preventing and / or spreading infectious diseases or mass non-communicable diseases (poisoning)». On the basis of the analysis of current criminal law norms and scientific positions, a possible way of improving the criminal law in this segment by introducing Article 325 in the new version was proposed.

Keywords: criminalization, infectious disease, poisoning; corpus delicti.

http://reyestr.court.gov.ua/Review/40408194 (дата звернення: 05.05.2020).

21. Вирок Здолбунівського районного суду Рівненської області від 15 лютого 2019 року. URL : http://reyestr.court. gov.ua/Review/80700987 (дата звернення: 05.05.2020).

22. Вирок Гагарінського районного суду міста Севастополя. URL : http://reyestr. court.gov.ua/Review/32154362 (дата звернення: 05.05.2020). 